\title{
The Effect of Self-Efficacy and Optimism toward Quality of Life on Transfemoral Prosthesis Users in Indonesia
}

\author{
Nur Rachmat \\ Department of Community Development/Empowerment, \\ Sebelas Maret University, Indonesia \\ Poltekkes Kemenkes Surakarta, Indonesia \\ Mohammad Fanani \\ Psychiatry Department, Medical Faculty, \\ Sebelas Maret University, Indonesia \\ Darsono Darsono \\ Department of Agribusiness, \\ Sebelas Maret University, Indonesia

\section{Suwarto Suwarto} \\ Department of Agriculture, \\ Sebelas Maret University, Indonesia
}

\begin{abstract}
Purpose: In persons with amputations, their quality of life decreases tremendously as a consequence of complex physical and psychological problems after losing an important part of their bodies. Therefore, a holistic and comprehensive rehabilitation approach post-amputation is needed to improve individual mobility and to help reintegrate into society. Method: This is a cross-sectional study involving 110 individuals with the transfemoral prosthesis. Data were collected using questionnaires and documentation and were analyzed using Multiple Linear Regressions. Results: Findings revealed a significantly positive effect of self-efficacy on quality of life $(p<0.001)$ and of optimism on quality of life $(p=0.001)$. Moreover, there is also a significant positive effect of selfefficacy and optimism together on the quality of life $(p<0.001)$. Conclusion: to improve quality of life of transfemoral prosthesis users, it is recommended to consider the role of persons' self-efficacy and optimism.
\end{abstract}

Keywords: Quality Of Life, Self-Efficacy, Optimism, Transfemoral Prosthesis, Indonesia

\section{INTRODUCTION}

In 2011 there were more than 5.6 million people died due to accident incidents and around 1.3 million people experienced physical disabilities. The incidence of lower limb fractures has a high prevalence of accidents at around 40\% [1]. The United States has 1.7 million people living with losing limbs. One in 190 Americans currently lives with losing limb and this number is expected to double in 2050 [2]. While the incidence of amputation in Indonesia reaches 25$30 \%$ of the total amputation lower limbs [3].

Trauma is the primary cause of foot amputation in developing countries and the second only for arterial disease devices in developed countries among civilians in the UK, trauma accounts for 7-9 percent of the 5,000 amputations performed annually. The prevalence is much higher, 
because traumatic amputations are usually young life expectation. In the United States, it is known that 45 post-amputation people experience trauma [4].

Quality of life is a multidimensional concept as an emotional and cognitive assessment of one's well-being, life satisfaction, enthusiasm and happiness [5,6]. Himself better assesses the life quality of a person because many aspects need to be considered to assess the life quality comprehensively [7].

Quality of life is often referred to as the overall sense of well-being related with a health perception and ability in a function [8]. The World Health Organization defines that life quality is the individual's perception of his or her position in the cultural situation and the value in which the individual lives and deals with his goals, hopes, principles and concerns. It means that life quality is a personal statement about a person's characteristics, satisfaction, adaptation against change, or health perception and well-being [9].

Amputation has a negative impact on patients such as physical, mental and social. The life quality automatically decreases after losing an important part of a person's body [6]. Therefore, it needs holistic and comprehensive rehabilitation approach [10]. The aim of rehabilitation after amputation is to improve individual mobility and to help reintegrate into society [11]. Self efficacy is a person's belief about his ability to overcome a variety of situations that arise in his life [12] People with disabilities in the context of social life needs attention and support for their social processes so that they feel accepted, can improve selfefficacy, and be able to achieve better health behaviors and how they face difficulties or failures [13].

Optimism is how far people expect a positive experience in the future. It is positively related to psychological well-being both a society in general and patients who are medically ill [14]. Optimism is positively related to psychological and negative well-being is associated with pressure and depression [15]. Pessimism is positively related to life quality and related to worse health [16]. Optimists are proven to have a higher quality of life than people with low optimism or pessimists [17]. The aim of this research is to investigate the effect of self-efficacy and optimism on quality of life on transfemoral prosthesis users.

\section{Study design}

\section{METHOD}

This is a cross sectional study that was conducted in PT Kuspito Prosthetic Orthotic. Prior the study, the study protocol had been approved by the ethic commission of the Faculty of Medicine Sebelas Maret University. Administrative clearance was obtained from the ministry of internal affairs Republic of Indonesia and National Unity and Community protection office, at district level and from PT Kuspito Prosthetic Orthotic.

\section{Participants}

In total, 110 patients with transfemoral prosthesis participated the study, patients from September to December 2018. The sampling technique in this study used purposive sampling. The inclusion criteria were transfemoral prosthesis users for at least 1 year, ready to fill out an informed consent sheet, and can be followed up periodically. The exclusion criteria were bilateral transfemoral amputation. The instrument for measuring self-efficacy variables is a questionnaire adopted from Suharsono and Istiqomah (2014) [18]. consists of 6 statement items using a Likert scale from a range of values from 1 to 4 . The instrument validity was tested and the results were obtained that the questionnaire was valid $(r \geq 0.453)$ and reliable ( $\alpha=0.814$ ) so that the questionnaire could be used for research. While the instrument for 
measuring optimism is a questionnaire adopted from Cahysari and Sakti (2014) [19]. Consists of 6 statement items using a likert scale from a value range of 1 to 4 , instrument validity tests have been carried out and the results are obtained that the questionnaire is valid $(\mathrm{r} \geq 0.527)$ and reliable ( $\alpha=0.785$ ) so that the questionnaire can be used for research.

The analysis in this study uses IBM SPSS Statistics 21, univariate analysis uses descriptive statistics in the form of frequency to describe the characteristics of the research sample. This study uses multiple regression to determine the effect of self efficacy and optimism on quality of life. It is said that there is a significant effect between self efficacy and optimism on quality of life if the $\mathrm{p}$ value is $<0.05$.

\section{RESULTS}

The majority of participants were males, in productive ages (21-50 years old), working independently $(38,2 \%)$, and finished their high school as the highest educational level attained. The participants' characteristics are presented in Table 1. Table 1 shows that the majority of respondents were 62 men (56.4\%) with age between $41-50$ years 38 people $(34.5 \%)$, working in the entrepreneurial sector was 42 people (38.2\%), high school was 49 people (44.6\%). The test results with multiple linear regressions for the effect of self-efficacy and optimism on the life quality of transfemoral prosthesis users can be seen in the Table 2 . Table 2 shows how selfefficacy and optimism influence quality of life. There is a significantly positive effect of selfefficacy and optimism on quality of life, either partially or together.

\section{DISCUSSION}

This study aims to analyze the effect of self-efficacy and optimism on quality of life in transfemoral prosthesis users. The results of data analysis showed that there is an effect of self-efficacy and optimism on quality of life in transfemoral prosthesis users $(p=0.000)$. This means that the higher the self-efficacy (confidence) and optimistic attitude in transfemoral prosthesis users will further improve their quality of life. This findings are important because Indonesia is an eastern country with a culture that is very shy especially people with disabilities. Self-efficacy and optimism need to be improved to improve their quality of life.

Low self-efficacy will cause difficulties such as shame, confusion, nervousness, and will be able to disrupt social relationships. Excessive low self-esteem will cause difficulties for individuals because individuals withdraw from social relationships [20]. Self-efficacy enables patients to feel, think, motivate themselves and behaves in achieving better health behaviors and how patients behave when faced with difficulties or failures [13].

Self-efficacy is the ability to regulate and carry out the actions which are needed to achieve the specified performance. It happens because they believe that the actions that are done can achieve the results we want, even though they have little incentive to act or to survive in the face of difficulties [12]. Individuals who have strong beliefs and steadfastness in their ability to do a task will continue to survive in their efforts even though they experience many difficulties and challenges [22].

The study also confirmed that optimism affects the quality of life on persons with transfemoral prosthesis. Optimism is the expectations that there will be better things are going to happen than bad things in the future [23]. Individuals are optimistic when facing difficulties and they will continue to try achieving the goals and will adjust to the situation at hand by using effective coping strategies to achieve the goals. 
Individual who are optimistic and pessimistic, have different ways of overcoming with problems, facing challenges, ways and results that are obtained in solving the difficulties, which are encountered. Optimists when facing challenges will face them confidently and persistence, although progress in resolving these challenges is slow because they believe a difficulty can be handled. Individuals who make universal explanations for failure, succumb to everything when failure happen, whereas individuals who make specific explanations can become weak in one part of life, but still persist in another part. People who are optimistic have a specific explanation of a problem so that it only creates powerlessness in the affected area. Optimistic individuals tend to blame bad events that happen to the external environment. Individuals who blame external events do not lose their self-respect when bad events occur [24].

\section{CONCLUSION}

Losing part of legs may not only limit person's mobility, but also impair the affected person's quality of life. Using transfermoral prosthesis can help persons with amputation to gain their daily functioning particularly which involving movement and mobility. The study reported the impact of self-efficacy and optimism on quality of life on persons with transfemoral prosthesis. More efforts should be done to promote self-efficacy and optimism on transfemoral prosthesis users to increase their quality of life.

\section{References}

Nurchairiah A.Y.H dan Ganis, I. 2014. Efektifitas kompres dingin terhadap intensitas nyeri pada pasien fraktur tertutup di Ruang Dahlia RSUD Arifin Ahmad. JOM. Vol 1 (2) : 1-9.

Peirano, AH and Franz, RW., 2012. Spirituality and Quality of Life in Limb Amputees. International Journal of Angiology Vol. 21 (2), pp.47-52.

Bactiar, D., Audy., Jamari., Budiwan. I. 2014. Perancangan Biomekanisme Sendi Protesa untuk Pasien Amputasi Tungkai di Atas Lutut dengan Desain Ergonomi dan Fleksibel. Prosiding SNST ke-5 Tahun 2014 Fakultas Teknik Universitas Wahid Hasyim Semarang.

Perkins, ZB., De'Ath, HD., Sharp, G., Tai, NRM. 2012. Factors Affecting Outcome After Traumatic Limb Amputation. British Journal of Surgery (Suppl 1) : 75-86.

Tate DG, Forchheimer M. 2002. Quality of Life, Life Satisfaction, and Spirituality: Comparing Outcomes Between Rehabilitation and Cancer Patients. Am J Phys Med Rehabil. Vol 8 (1), pp. 400-410

Wald. J. 2004. Psychological Factors in Work-Related Amputation: Consideration for Rehabilitation Counsellors. Journal of rehabilitation, Vol 70 (4), pp. 6-15.

Sinha, R dan Heuvel, W. 2011. A systematic literature review of quality of life in lower limb amputees. Disability and Rehabilitation, Vol 33 (11), pp. 883-899.

Bare BG., Smeltzer SC. (2010). Buku Ajar Keperawatan Medikal Bedah. Jakarta : EGC. Hal : 45-47

Godoy, Adriana de, Rodrigo J, Morita, Beatriz R. Cordenunsi, Franco M. Lajolo dan Joao Roberto O. Do Nascimento. 2009 Expression analysis of a set of genes related to the ripening of bananas anf mangoed. Brazilian Society of Plant Physiology. Vo. 21(4).

Agarwal P. K., Singh, A., Gaurav, K., Goel, S., Khanna, H. D, Goel R. K. 2008. Evaluation of Wound Healting Activity of Extracts of Plantain Banana. (Musa sapientum var. paradisiaca) in rats. Indian J. Exp. Biol. 2009; 47: 32240

Bhaskaranand, K., Bhat, AK., Acharya, KN. 2003. Prosthetic Rehabilitation in Traumatic Upper Limb Amputees (an Indian perspective).

Bandura, A. (2006). Article of guide for Contructing Self Efficacy Scales. by Information Age Publishing.

Faltas, S.F.M. and Ameen, DA. 2015. Self-Eficacy of Patients with Lower Limb Amputation: Nursing Guidelines. 12 th International Congress Integration of Scientific Research, Education Evidence Based Practice in Nursing.

Scheier MF and Carver CS. 1992. Effects of optimism on pychological and physical well-being: Theoretical overview and empirical update. Cognitive Therapy and Research. 1992; 16(2):201-228. 
Rachmat, N., Fanani, M., Darsono, D., \& Suwarto, S. (2020). The Effect of Self-Efficacy and Optimism toward Quality of Life on Transfemoral Prosthesis Users in Indonesia. Advances in Social Sciences Research Journal, 7(1) 153-157.

Horney DJ, Smith HE, McGurk M, Weinman J, Herold J, Altman K, 2011. Associations between quality of life, coping styles, optimism, and anxiety and depression in pretreatment patients with head and neck cancer. Head \& Neck. 2011; 33 (1): 65-71.

Petersen LR, Clark MM, Novotny P, Kung S, Sloan JA, Patten CA. 2008. Relationship of Optimism-Pessimism and Health-Related Quality of Life in Breast Cancer Survivors. Journal of Psychosocial Oncology. Vol 26 (4) :15-32.

Conversano C, Rotondo A, Lensi E, Della Vista O, Arpone F, Reda MA. Optimism and its impact on mental and physical well-being. Clin Pract Epidemiol Ment Health. 2010;6:25-9.

Suharsono, Y., \& Istiqomah. (2014). Validitas dan reliabilitas skala self efficacy. Jurnal Ilmiah Psikologi Terapan, 2(1).

Cahyasari, A. S. M., \& Sakti, H. (2014). Optimisme Kesembuhan Pada Penderita Mioma Uteri. Jurnal Psikologi, 13(1),

Ambarika, R., et al. 2015. Analisis Faktor yang Berhubungan dengan Perilaku Waspada Stroke pada Kelompok Resiko Tinggi di Wilayah Kerja Puskesmas Poncokusumo Malang (Pendekatan Teori Health Promotion Model Nolla J. Pender). The Indonesian Journal of Health Science, 5(2): 223-242.

Mahmoudi, G., Rostami, FH., Mahmoudjanloo, S., Jahani, MA. 2017. Relationship of Employees' Achievement Motivation and Quality of Working Life with Their Self-efficacy at Selected Hospitals with a Multi-group Analysis: Moderating Role of Organizational Ownership. Mater Sociomed. Vol 29 (4) : 237-241.

Kreis, S; Molto, A; Baily, F; Dadoun, S; Fabre, S; Rein, C. 2015. Relationship between Optimism and Quality of Life in Patients with Two Chronic Rheumatic Diseases: Axial Spondyloarthritis and Chronic Low Back Pain: a Cross Sectional Study of 288 Patients. Health and Quality of Life Outcomes Vol (78) : 1-6

Carver, C. S., Scheier, M. F., \& Segerstrom, S. C. 2010. Optimism. Clinical Psychology Review. 30 (1), pp. $879-889$

Seligman, Martin E.P. (1990), Learned Optimism: How to Change Your Mind and Your Life, New York: Pocket Books.

21-33 